\section{Efficient Plant Regeneration from Suspension-cultured Cells of Tall Bearded Iris}

\author{
Yuexin Wang ${ }^{1}$, Zoran Jeknic ${ }^{2}$, Richard C. Ernst ${ }^{3}$, and \\ Tony H.H. Chen ${ }^{4}$ \\ Department of Horticulture, ALS 4017, Oregon State University, Corvallis, \\ OR 97331-7304
}

Additional index words. tissue culture, embryogenesis, organogenesis, 2,4-D, Kin, NAA, BA

\begin{abstract}
A protocol was developed for efficient plant regeneration of Iris germanica $\mathbf{L}$. 'Skating Party' from suspension cultures. Suspension cultures were maintained in Murashige and Skoog (MS) basal medium (pH 5.9) supplemented with $290 \mathrm{mg} \cdot \mathrm{L}^{-1}$ proline, $50 \mathrm{~g} \cdot \mathrm{L}^{-1}$ sucrose, $5.0 \mu_{\mathrm{M}} 2,4-\mathrm{D}$, and $0.5 \mu_{\mathrm{M} \mathrm{Kin}}$. Suspension-cultured cells were transferred to a shoot induction medium (MS basal medium supplemented with $10 \mathrm{mg} \cdot \mathrm{L}^{-1}$ pantothenic acid, $4.5 \mathrm{mg} \cdot \mathrm{L}^{-1}$ nicotinic acid, $1.9 \mathrm{mg} \cdot \mathrm{L}^{-1}$ thiamine, $250 \mathrm{mg} \cdot \mathrm{L}^{-1}$ casein hydrolysate, 250 $\mathrm{mg} \cdot \mathrm{L}^{-1}$ proline, $50 \mathrm{~g} \cdot \mathrm{L}^{-1}$ sucrose, $2.0 \mathrm{~g} \cdot \mathrm{L}^{-1}$ Phytagel, $0.5 \mu_{\mathrm{M}} \mathrm{NAA}$, and $\left.12.5 \mu_{\mathrm{M}} \mathrm{Kin}\right)$. Cell clusters that proliferated on this medium differentiated and developed shoots and plantlets in about 5 weeks. Regeneration apparently occurred via both somatic embryogenesis and shoot organogenesis. A series of experiments was conducted to optimize conditions during suspension culture to maximize subsequent plant regeneration. Parameters included 2,4-D and Kin concentrations, the subculture interval, and the size of cell clusters. The highest regeneration rate was achieved with cell clusters $\leq 280 \mu \mathrm{m}$ in diameter, derived from suspension cultures grown for 6 weeks without subculturing in liquid medium containing $5 \mu_{\mathrm{M}}$ 2,4-D and $0.5 \mu_{\mathrm{M}} \mathrm{Kin}$. Up to 4000 plantlets with normal vegetative growth and morphology could be generated from $1 \mathrm{~g}$ of suspension-cultured cells in about 3-4 months. Chemical names used: 2,4-dichlorophenoxyacetic acid (2,4-D); kinetin (Kin); 1naphthaleneacetic acid (NAA).
\end{abstract}

Iris germanica is one of the horticulturally most important tall bearded irises in the genus. Hundreds of valuable cultivars from this species have been developed and cultivated commercially as perennial ornamental plants. Traditionally, rhizomatous iris plants are propagated by splitting rhizomes, with a maximum annual yield of 10 plants/rhizome (Jéhan et al., 1994). This practice is inefficient and slow, especially for propagating new cultivars for commercial use. Propagation by seed is impractical because of low germination rates and the allogamous nature of iris. Therefore, a more efficient propagation method is needed. Also, strong consumer demand increases the challenge of developing new cultivars with novel flower characteristics. Introducing desirable traits by genetic transformation would offer an attractive means for iris cultivar improvement.

Received for publication 28 July 1998 . Accepted for publication 10 Dec. 1998. Oregon Agricultural Experiment Station technical paper no. 11376. We thank Mr. Alfred Soeldner for his help with SEM and Dr. Machteld Mok, Dr. Barbara Reed, and Dr. Roberto Valverde for their helpful reviews. The cost of publishing this paper was defrayed in part by the payment of page charges. Under postal regulations, this paper therefore must be hereby marked advertisement solely to indicate this fact.

${ }^{1}$ Graduate Research Assistant.

${ }^{2}$ Faculty Research Assistant.

${ }^{3}$ President and General Manager, Cooley's Gardens, P.O. Box 126, Silverton, OR 97381.

${ }^{4}$ Professor and corresponding author: Phone: (541) 7375444; fax: (541) 737-3479; e-mail: chent@bcc.orst.edu
Plant regeneration from somatic tissues is generally considered a prerequisite to genetic transformation. Many efforts have been made to induce plant regeneration via in vitro callus culture of various explant types from several iris species (Fujino et al., 1972; Gozu et al., 1993; Hussey, 1976; Laublin et al., 1991; Meyer et al., 1975; Radojević and Landré, 1990; Radojević et al., 1987; Radojević and Subotić, 1992; van der Linde et al., 1988; Yabuya et al., 1991). In I. germanica, Reuther (1977) induced embryogenic calli from zygotic embryos and Jéhan et al. (1994) regenerated plants via somatic embryogenesis from leaves, rhizome apices, and immature flowers. Shimizu et al. (1996) cultured protoplasts and regenerated plants via somatic embryogenesis. Shimizu et al. (1997) induced embryogenic calli from three cultivars of I. germanica, but was able to induce regeneration from suspension cultures in only one. Unfortunately, low efficiency of plant regeneration in $I$. germanica and other iris species hinders development of a suitable system for genetic transformation.

One advantage of suspension culture vs. callus culture is that it provides a convenient means for studying the behavior of isolated single cells or small cell aggregates during growth, differentiation, and regeneration. Millions of cells or cell aggregates can be maintained in a single culture vessel and are easily multiplied by dividing the cultures and routinely subculturing them. In addition, suspension-cultured cells or cell aggregates can be induced to produce many plantlets in a short time. This is especially true for monocots, in which in vitro plant regeneration generally has been more difficult than in dicots (Kamo et al., 1990; Wang and Nguyen, 1990). Plant regeneration from suspension-cultured cells generally involves four steps: initiation of friable callus; establishment of the suspension culture; induction of somatic embryogenesis or organogenesis; and shoot and root development.

Establishing cell suspension cultures is important because suspension cells generally have the highest capacity for plant regeneration (Ammirato, 1978; Novak et al., 1989; Tsukahara et al., 1996), but successful regeneration from such cells has been reported only in a few ornamental monocots (Kamo et al., 1990; Shimizu et al., 1997). Regeneration from cell suspension culture of iris is possible, but the efficiency is low (Shimizu et al., 1997).

The main objective of this study was to establish an efficient and reproducible plant regeneration protocol from suspension-cultured cells of Iris germanica that would be suitable for genetic transformation. To achieve this goal, several parameters in the suspensionculture phase were systematically tested for their specific effects on subsequent plant regeneration. Here, we report the development of an efficient plant regeneration system.

\section{Materials and Methods}

Plant material and culture medium. Greenhouse-grown plants of Iris germanica 'Skating Party' were used as source material. Plants were grown in individual 4-L pots containing a mixture of 1 peatmoss : 2 pumice : 1 sandy loam (by volume) in a greenhouse at $25^{\circ} \mathrm{C} \pm$ $3{ }^{\circ} \mathrm{C}$ day $/ 20{ }^{\circ} \mathrm{C} \pm 3{ }^{\circ} \mathrm{C}$ night and a $16-\mathrm{h}$ photoperiod, with natural light supplemented by high-pressure sodium lamps (Energy Technics, York, Pa.) to give a photosynthetically active radiation of $400-500 \mu \mathrm{mol} \cdot \mathrm{m}^{-2} \cdot \mathrm{s}^{-1}$. Plants were fertilized with controlled-release fertilizer Nutricote-Type 100 (16-10-10) (Fertilizer Co. Ltd., Tokyo) every 2-3 months. Each year, the plants were divided by splitting the rhizome and repotting in fresh soil mix. Media used for in vitro culture and plant regeneration are listed in Table 1.

Establishment and maintenance of suspension cultures. Newly sprouted shoots $(\approx 40$ to $50 \mathrm{~mm}$ tall) were excised from the stock plants and used for callus induction. Two to three of the outermost leaves were removed from each shoot. The basal portions were excised and washed thoroughly with tap water, immersed in $70 \%$ ethanol for $1 \mathrm{~min}$, then in $1 \%$ sodium hypochlorite containing Tween 20 (two to three drops $/ 100 \mathrm{~mL}$ ). They were gently shaken on a rotary shaker (100 rpm) for $25 \mathrm{~min}$, and then rinsed three times with sterile water. The basal portion of each leaf was carefully separated from the shoot and sliced into $\approx 5-\mathrm{mm}$ thick pieces. The explants were placed on MS$\mathrm{C}$ medium (Table 1) to induce callus development. Calli were cultured in the dark at $25^{\circ} \mathrm{C}$ and subcultured every 3 weeks on the same type of medium.

To establish suspension cultures, $\approx 1 \mathrm{~g}$ of 
Table 1. Media for in vitro iris culture and plant regeneration.

\begin{tabular}{|c|c|c|}
\hline Medium & Function & Composition \\
\hline MS-C & Callus induction and maintenance & $\begin{array}{l}\text { MS basal medium [Murashige and Skoog, } 1962 \\
\text { (Sigma M5519)], } 290 \mathrm{mg} \cdot \mathrm{L}^{-1} \text { proline, } 50 \mathrm{~g} \cdot \mathrm{L}^{-1} \\
\text { sucrose, } 5.0 \mu \mathrm{M} \text { 2,4-D, and } 1.0 \mu \mathrm{M} \text { Kin, } 3.0 \mathrm{~g} \cdot \mathrm{L}^{-1} \\
\text { Phytagel, pH 5.9 }\end{array}$ \\
\hline MS-L & Suspension culture maintenance & MS-C medium without Phytagel \\
\hline MS-I & Shoot induction & $\begin{array}{l}\text { MS basal medium, } 250 \mathrm{mg} \cdot \mathrm{L}^{-1} \text { proline, } 250 \mathrm{mg} \cdot \mathrm{L}^{-1} \\
\text { casein hydrolysate, } 10 \mathrm{mg} \cdot \mathrm{L}^{-1} \text { pantothenic acid, } \\
4.5 \mathrm{mg} \cdot \mathrm{L}^{-1} \text { niacin, } 1.9 \mathrm{mg} \cdot \mathrm{L}^{-1} \text { thiamin, } 50 \mathrm{~g} \cdot \mathrm{L}^{-1} \\
\text { sucrose, } 2.0 \mathrm{~g} \cdot \mathrm{L}^{-1} \text { Phytagel, } 12.5 \mu \mathrm{M} \text { Kin, and } \\
0.5 \mu \mathrm{M} \text { NAA, pH } 5.7\end{array}$ \\
\hline MS-D & Shoot elongation and development & $\begin{array}{l}\text { MS-I medium without Kin and NAA supplemented } \\
\text { with } 1.25 \mu \mathrm{M} \text { BA }\end{array}$ \\
\hline MS-R & Rooting and development of plantlets & MS-I medium without growth regulators \\
\hline
\end{tabular}

callus tissue was transferred to each $250-\mathrm{mL}$ Erlenmeyer flask containing $75 \mathrm{~mL}$ of MS-L medium (Table 1), incubated in the dark at 23 ${ }^{\circ} \mathrm{C}$ on a rotary shaker at $100 \mathrm{rpm}$, and subcultured monthly.

Plant regeneration. Six-week-old suspension cultures were filtered through a 30-mesh stainless screen (Sigma Chemical Co., St. Louis) to remove large cell aggregates. The pass-through fraction was collected in $50-\mathrm{mL}$ sterile tubes and centrifuged at $1000 g_{\mathrm{n}}$ for 5 min in a clinical centrifuge (HN-SII, International Equipment Co., Needham Heights, Mass.). The pelleted cells were weighed and resuspended in MS-I medium (Table 1) without Phytagel at $0.2 \mathrm{~g} \cdot \mathrm{mL}^{-1}$ final density. A 0.5 $\mathrm{mL}$ aliquot was inoculated onto each $15 \times 60$ $\mathrm{mm}$ sterile plastic plate containing $20 \mathrm{~mL}$ of solid MS-I medium to induce somatic embryogenesis. The plates were incubated in the dark at $25^{\circ} \mathrm{C}$ for 5 weeks.

The clumps of induced structures were transferred to Magenta GA-7 vessels (Sigma) containing $50 \mathrm{~mL}$ of MS-D medium (Table 1). Clumps were cultured at $23{ }^{\circ} \mathrm{C}$ under light $\left(\approx 50 \mu \mathrm{mol} \cdot \mathrm{m}^{-2} \cdot \mathrm{s}^{-1}\right.$ for $\left.16 \mathrm{~h} / 24 \mathrm{~h}\right)$ for 6 weeks for shoot elongation and development. Clumps of well-developed shoots with or without roots were transferred to MS-R medium (Table 1) for induction and further development of roots under the same conditions for 5 more weeks. Plantlets were transferred to a soil mix (1 peatmoss : 1 perlite : 1 sandy loam, by volume) in $1.5-\mathrm{L}$ pots and acclimatized on a mist bench (relative humidity $95 \%$ to $98 \%$ ) in the greenhouse. After 4 weeks, they were transferred to a bench without mist and fertilized with Nutricot-Type 100 controlled-release fertilizer.

Effects of 2.4-D and Kin. We tested 20 combinations of 2,4-D $(0.0,1.0,5.0,25.0$, and $125.0 \mu \mathrm{M})$ and Kin $(0.0,0.5,2.5$, and $12.5 \mu \mathrm{M})$ in MS-L medium. Two grams of suspension tissue were inoculated into each $250-\mathrm{mL} \mathrm{Er}$ lenmeyer flask containing $50-\mathrm{mL}$ of medium supplemented with various combinations of 2,4-D and Kin and incubated for 6 weeks. The cultures were then inoculated onto MS-I medium to induce plant regeneration as above. The numbers of differentiated and regenerating clumps were determined and expressed as numbers of clumps/gram cells. The effect of different combinations of 2,4-D and Kin on synchronous development of shoots and roots was scored 5 weeks after the differentiated clumps were transferred to MS-D medium.
Effect of subculture interval. Suspension cultures used for this test were continuously incubated in MS-L medium for up to 9 weeks without being subcultured. Samples were removed weekly from Week 4 to Week 9 and subjected to all the steps in our general procedure for plant regeneration. The numbers of differentiated and regenerating clumps were determined and expressed as numbers of clumps/gram cells.

Effect of size of cell clusters. Six-week-old suspension cultures were subsequently screened through a series of five differentsized stainless sieves (Sigma), including mesh sizes $10(1910 \mu \mathrm{m}), 20(860 \mu \mathrm{m}), 30(520 \mu \mathrm{m})$, $40(380 \mu \mathrm{m})$, and $50(280 \mu \mathrm{m})$. (Pore size of a particular mesh sieve is given in parentheses.) Each fraction retained on a screen was collected separately and assigned the number of the corresponding mesh size. All the cells passing through the 50-mesh sieve were collected and designated as P50. The largest cell aggregates, retained on the 10-mesh sieve, were discarded, because in preliminary experiments cell aggregates $\geq 2 \mathrm{~mm}$ diameter exhibited low regeneration capability. Each fraction was weighed and resuspended in MSI medium without Phytagel at $0.2 \mathrm{~g} \cdot \mathrm{mL}^{-1}$ final density. A $0.5-\mathrm{mL}$ aliquot of each fraction was inoculated on each of five replicate plates (15 $\times 60 \mathrm{~mm}$ ) of solid MS-I medium. Plant regeneration was carried out as outlined above, and the numbers of differentiated and regenerating clumps were determined and expressed as numbers of clumps/gram cells.

Scanning electron microscopy (SEM). Samples from several different stages of differentiation were excised from tissues grown on MS-I medium and fixed overnight at $4{ }^{\circ} \mathrm{C}$ in $2 \%$ glutaraldehyde in $0.05 \mathrm{~m}$ sodium phosphate buffer, $\mathrm{pH}$ 7.2. Samples were washed in the same buffer without glutaraldehyde for $\approx 2$ $\mathrm{h}$ and dehydrated with a graded ethanol series. Samples were dried in a CPD 020 critical point dryer (Balzers Union, Liechtenstein) and mounted on either "Spot-o-glue" adhesive tabs (Avery, Azusa, Calif.) or conductive carbon tabs (Ted Pella, Redding, Calif.) on SEM stabs. Samples were coated with 60 gold : 40 palladium (w/w) in an Edwards S150B sputter coater (Crawley, England) and examined with a scanning electron microscope (3300FE; Amray, Bedford, Mass.).

Data collection and analysis. In all experiments concerning suspension cultures, the data were expressed as the number of differentiated clumps per gram cells on MS-I medium. Data were collected and processed for each of five duplicated plates, and each entire experiment was repeated three times. At the developing stage, 15 to 30 differentiated clumps or regenerating clumps were transferred to three to six GA-7 Magenta vessels containing MS-D medium. We counted the number of differentiated clumps per gram tissue and the number of regenerating clumps that developed both shoots and roots or shoots only on the MS-D medium. The data were subjected to analysis of variance (ANOVA) and Duncan's multiple range test $(P \leq 0.05)$.

\section{Results}

Establishment and maintenance of suspension cultures. The callus induction rate was investigated 6 weeks after the leaf pieces were placed on MS-C medium. Callus induction capabilities of different leaf positions differed greatly (data not shown). The highest rate of callus induction $(>80 \%)$ was from the $2-\mathrm{cm}$ basal portions of the two innermost leaves. Two types of induced calli, i.e., compact and friable, were identified. Initially, we tried to establish suspension cultures from both types of calli. When friable calli were inoculated into the MS-L medium, they developed into dispersible cell aggregates after two to three subcultures. Stable suspension cultures were successfully established after three to five subcultures and were maintained by subculturing every 3 weeks in the same medium. However, we were unable to obtain suspension cultures from compact calli because they grew and separated into large clumps in the MS-L medium even after repeated subculturing.

Morphogenesis of plant regeneration. To verify the morphogenic process of plant regeneration from the suspension cultures, cells collected by centrifugation were placed on the MS-I medium and incubated for up to 5 weeks. The morphogenesis of these cultures was recorded weekly. Initiation and development of differentiated structures did not occur synchronously. When the suspension cultures were inoculated onto the solid MS-I medium, they appeared as irregular, multicellular aggregates (Fig. 1A), containing from several to hundreds of cells. A few days to 2 weeks after being placed on the MS-I medium, the cell aggregates began to enlarge. After $\approx 2$ weeks the first visually identifiable opaque calli had formed (Fig.1B). Close examination of those structures by SEM revealed the formation of a large number of globular nodules (Fig. 2A). One to 2 weeks later, some of the calli underwent further growth and differentiation and appeared as independent, white, globular structures closely resembling globular embryos (Figs. $1 \mathrm{C}$ and $2 \mathrm{~B}$ ). Soon thereafter, the majority of globular embryo-like structures started to elongate (Figs. 1D and 2C) and in the next few weeks differentiated into shoot apices (Figs. $1 \mathrm{E}$ and $2 \mathrm{D})$. However, few or no roots developed at this time, and many of those that did develop were not directly connected to devel- 

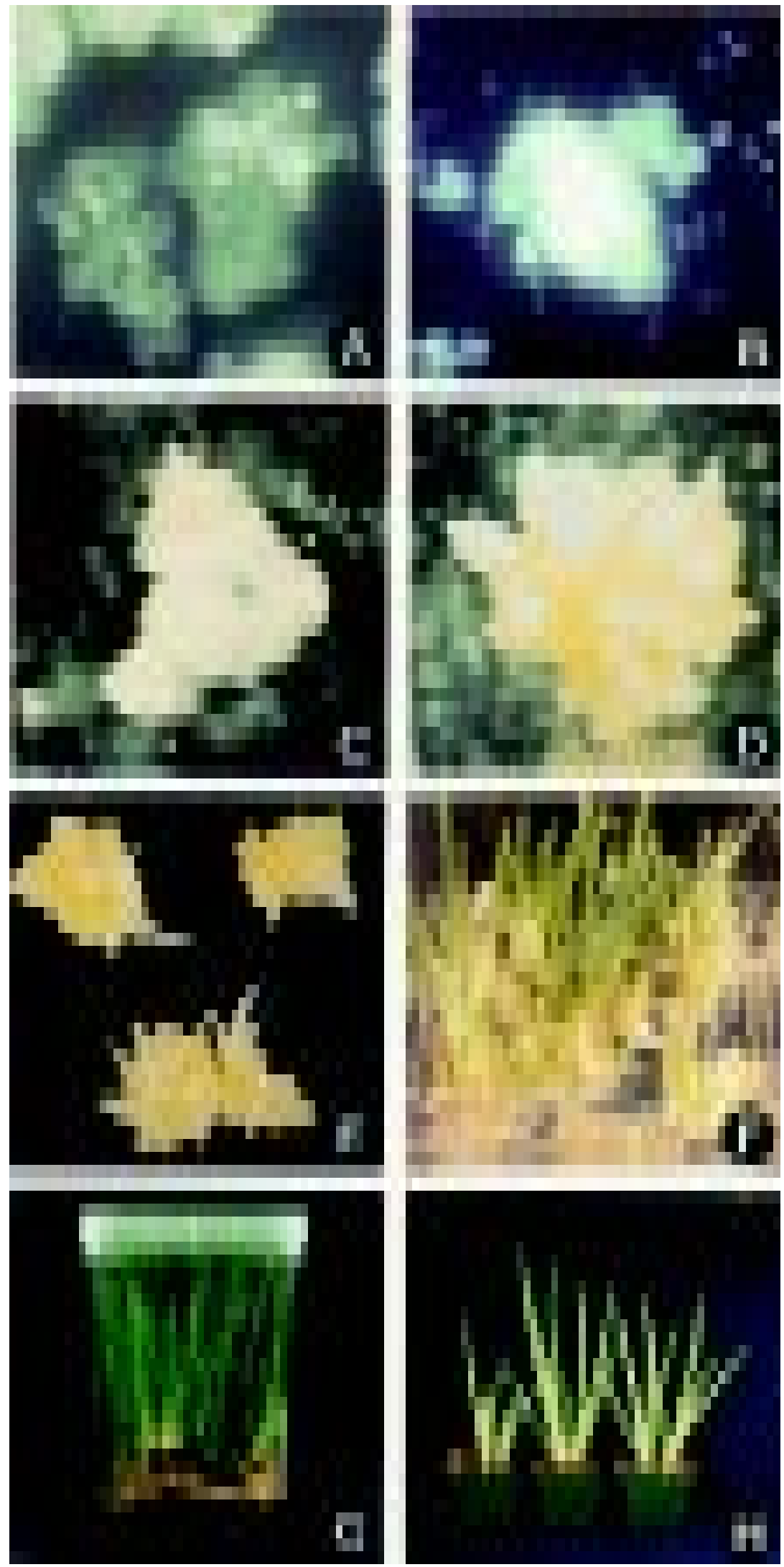

Fig. 1. Morphogenesis in suspension-cultured cells of Iris germanica 'Skating Party.' (A) A multicellular mass from suspension culture immediately after transfer onto MS-I medium. (B) The cell aggregates after enlarging and becoming visually identifiable as opaque calli a few days to several weeks later. (C) Calli further differentiated into globular, embryo-like structures 1-2 weeks thereafter. (D) Elongation and development of embryo-like structures into shoot primordia $(\mathbf{E})$ or shoot apices with or without roots. (F) Shoots and plantlets on MS-D medium. (G) Development of plantlets, and development and rooting of shoots on MS-R medium. (H) Plantlets acclimatized under greenhouse conditions. oping shoots. When those structures were transferred to the MS-D medium containing 1.25 $\mu \mathrm{M}$ 6-benzyladenine (BA), $80 \%$ to $90 \%$ developed into plantlets with or without roots (Fig. $1 F)$. Both shoots and plantlets were transferred to MS-R medium to facilitate root differentiation and development. The majority of shoots developed roots within 5 weeks (Fig. $1 \mathrm{G})$. After 5 weeks on MS-R medium there were no apparent differences in either size or development stage between newly rooted shoots and those plantlets that had already developed both shoots and roots on the MS-D medium. The number of regenerated shoots ranged from 15 to 20 shoots per clump. Regenerated plants were eventually transferred to pots containing soil mix, and were readily acclimatized under greenhouse conditions (Fig. 1H).

Effects of 2,4-D and Kin combinations. Among the various 2,4-D and Kin combinations, the MS-L medium containing $5.0 \mu \mathrm{M}$ 2,4-D and $0.5 \mu \mathrm{M}$ Kin promoted significantly more differentiated clumps $(P \leq 0.05)$ than did other media, and these produced single or joined induced structures (Fig. 3A). MS-L medium with $0.5 \mu \mathrm{M}$ Kin in combination with all evaluated concentrations of 2,4-D generally gave rise to the best differentiation (Fig. 3A). The MS-L medium with $5.0 \mu \mathrm{M} 2,4-\mathrm{D}$ in combination with $0.5 \mu \mathrm{M}$ Kin or without Kin consistently yielded the most regenerating clumps, i.e., the clumps that survived the transfer from MS-I to MS-D medium and subsequently developed into shoots or plantlets (Fig. 3B). Cells grown in MS-L medium containing 5.0 $\mu_{\mathrm{M}}$ 2,4-D consistently developed both shoots and roots simultaneously during the regeneration process (Fig. 4A). The same level of 2,4-D in MS-I medium enhanced subsequent shoot development on MS-D medium (Fig. 4B). ANOVA for plant regeneration showed that main effects of both Kin and 2,4$\mathrm{D}$ were highly significant $(P \leq 0.01)$.

Interaction of Kin and 2,4-D was also significant for three of the four measured responses (Table 2).

Effect of subculture interval. Suspension cells collected from cultures maintained for 6 weeks without subculturing consistently developed the most differentiated clumps per gram tissue on MS-I medium (Fig. 5). Many differentiated clumps derived from the 6-weekold cultures survived the transfer from MS-I to MS-D medium, and grew into healthy shoots or plantlets. Such clumps are referred to as "regenerating clumps." However, when cells were collected from suspension cultures maintained in the MS-L medium for $<6$ weeks, the numbers of both differentiated and regenerating clumps were dramatically lower. Suspension cells collected from suspension cultures maintained for more than 7 weeks without subculturing failed to regenerate.

Effect of size of cell clusters. The numbers of both differentiated clumps and regenerating clumps per gram tissue strongly depended on the size of cell aggregates found in the suspension cultures (Fig. 6). The smaller the cell clusters the higher the numbers of both clump types obtained. Cell fractions passing through 

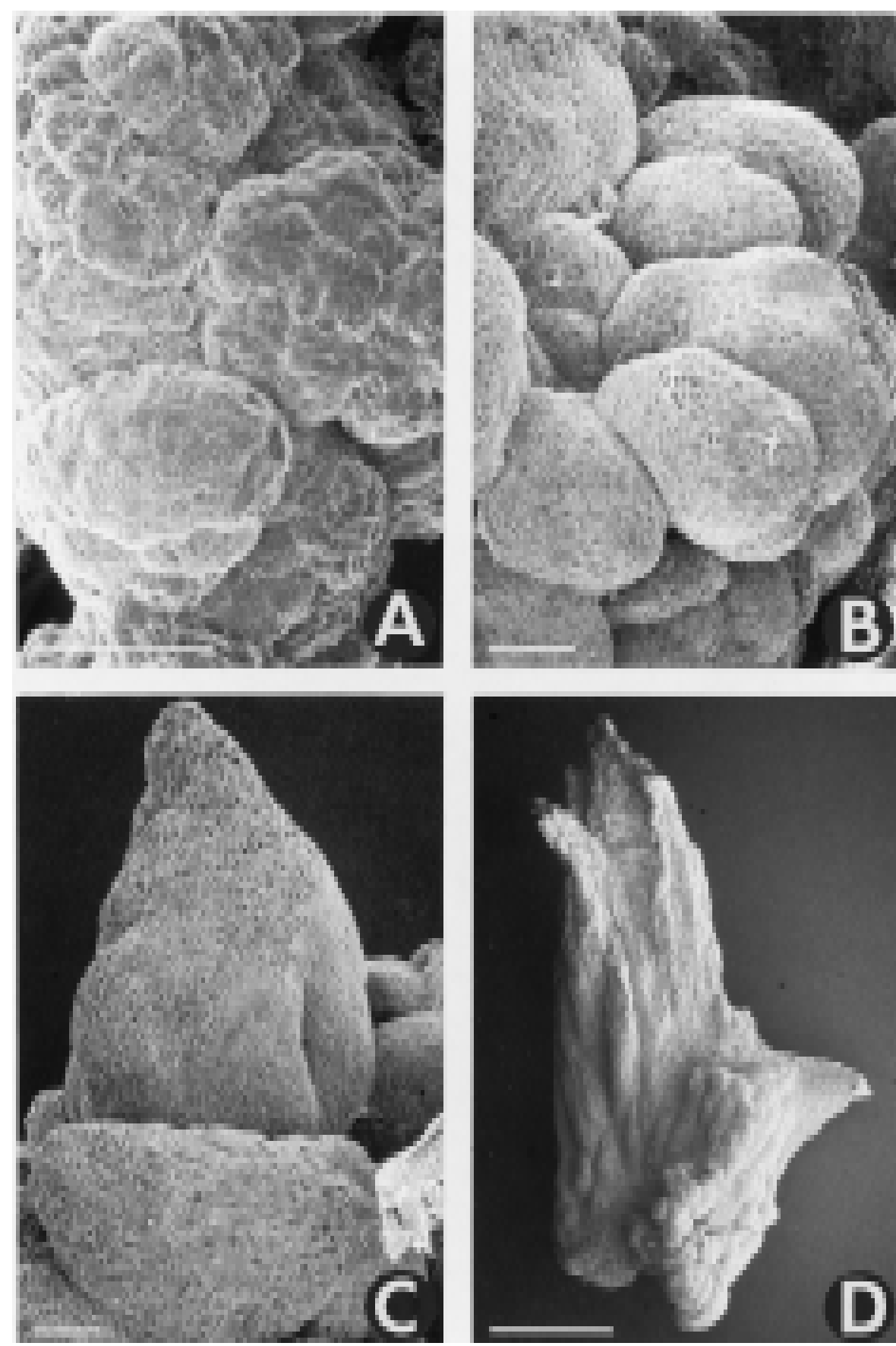

Fig. 2. Scanning electron micrographs of several early stages of plant regeneration from suspension cultures of Iris germanica. (A) Development of globular nodules after a few days to 2 weeks on MS-I medium. (B) Globular, embryo-like structures 1-2 weeks later. (C) Development of several shoot primordia from the globular embryo-like structures. (D) A regenerated shoot apex. Bar sizes: A, B, and C $=100 \mu \mathrm{m}$; $\mathrm{D}=1 \mathrm{~mm}$.

the 30-mesh sieve (fractions 40, 50, and P50) generally produced more of both differentiated and regenerating clumps. The fraction passing through the 50-mesh sieve (fraction P50) produced the greatest numbers of both differentiated clumps and regenerating clumps per gram tissue.

\section{Discussion}

Friable calli are usually considered a prerequisite for establishing cell suspension cultures. Lu and Vasil (1981) and Vasil and Vasil the nucleus (Mitra et al., 1960; Smith and Street, 1974; Torrey, 1958, 1967) or physiological changes (Reinert and Backs, 1968; Reinert et al., 1970; Steward, 1967; Sussex and Frei, 1968; Syono, 1965). However, our suspension cultures from Iris germanica 'Skating Party' maintained for more than 3 years via repeated subculture still demonstrated high regeneration capacity. Furthermore, there were few grossly aberrant phenotypes $(<1 \%)$ among more than 500 regenerated plants (data not shown). Plants with aberrant phenotypes had yellow or white streaking on leaves and a few plants were slow growing.

In vitro regeneration of iris was assumed to be via somatic embryogenesis (Jéhan et al., 1994; Laublin et al., 1991; Radojević et al., 1987; Shimizu et al., 1996, 1997). However, in a detailed anatomical study of Iris setosa Pall. ex Link., Radojević and Subotić (1992) demonstrated both somatic embryogenesis and organogenesis. In the current study, suspension-cultured cells differentiated many globular nodules 2-3 weeks after transfer to MS-I medium and then developed globular embryolike structures. Further morphogenesis of globular structures on MS-D medium seemed to be via both somatic embryogenesis and organogenesis.

The efficiency of regeneration from suspension-cultured iris cells in this study was much higher than that reported from in vitro callus culture of iris on solid media (Fujino et al., 1972; Gozu et al., 1993; Hussey, 1976; Jéhan et al., 1994; Laublin et al., 1991; Meyer et al., 1975; Radojević and Landré, 1990; Radojevićand Subotić, 1992; Radojevićet al., 1987; Reuther, 1977; van der Linde et al., 1988; Yabuya et al., 1991). Shimizu et al. (1997) reported plant regeneration frequency of $\approx 36$ shoots $/ 20 \mathrm{mg}$ of suspension-cultured cells. Under optimal conditions, we could produce $\approx 4000$ iris plantlets per gram of screened cells, or $\approx 2$-fold that reported by Shimizu et al. (1997). This is based on $\approx 180$ regenerating clumps per gram cells (Fig. 6) and $\approx 15-20$ shoots/clump. To date, this represents the most efficient regeneration system of iris plants from suspension-cultured cells. This system would allow mass propagation of desirable iris genotypes and would also make genetic transformation possible.

Growth regulators exerted the most critical influence on plant regeneration from iris suspension cultures. Shimizu et al. (1996) combined $2 \mathrm{mg} \cdot \mathrm{L}^{-1} 2,4-\mathrm{D}$ and $0.1 \mathrm{mg} \cdot \mathrm{L}^{-1} \mathrm{Kin}$ to initiate friable calli from leaf bases of $I$. germanica ' $\mathrm{G} 1$ '. To establish suspension cultures, however, they reduced $2,4-\mathrm{D}$ to $1 \mathrm{mg} \cdot \mathrm{L}^{-1}$ and increased Kin to $1 \mathrm{mg} \cdot \mathrm{L}^{-1}$. The concomitant decrease in 2,4-D with an increase in Kin concentration generally enhanced cell growth and the initiation of proembryogenic cellular aggregates (Kamo et al., 1990; Tsukahara et al., 1996). To maintain the suspension culture, the concentration of 2,4-D is especially important. Vasil (1988) suggested that 1 to 2.5 $\mathrm{mg} \cdot \mathrm{L}^{-1} 2,4-\mathrm{D}$ was critical in preserving the embryogenic nature of wheat cultures. However, further differentiation of proembryogenic calli into mature, regenerated structures oc- 


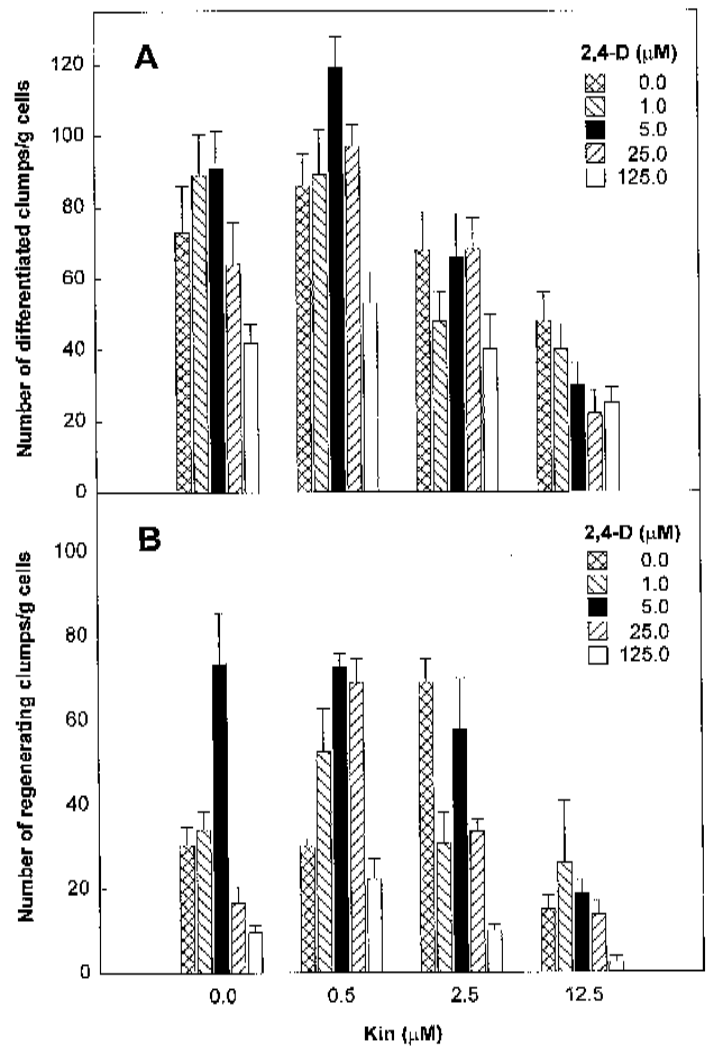

Fig. 3. Effects of 2,4-D and Kin combinations in MS-L medium on (A) number of differentiated clumps/ gram cells 5 weeks after suspension-cultured iris cells were transferred to the MS-I medium, and (B) number of regenerating clumps/gram cells 5 weeks after differentiated clumps were transferred to MS$\mathrm{D}$ medium. Bars represent standard errors of the means, $\mathrm{n}=15$.

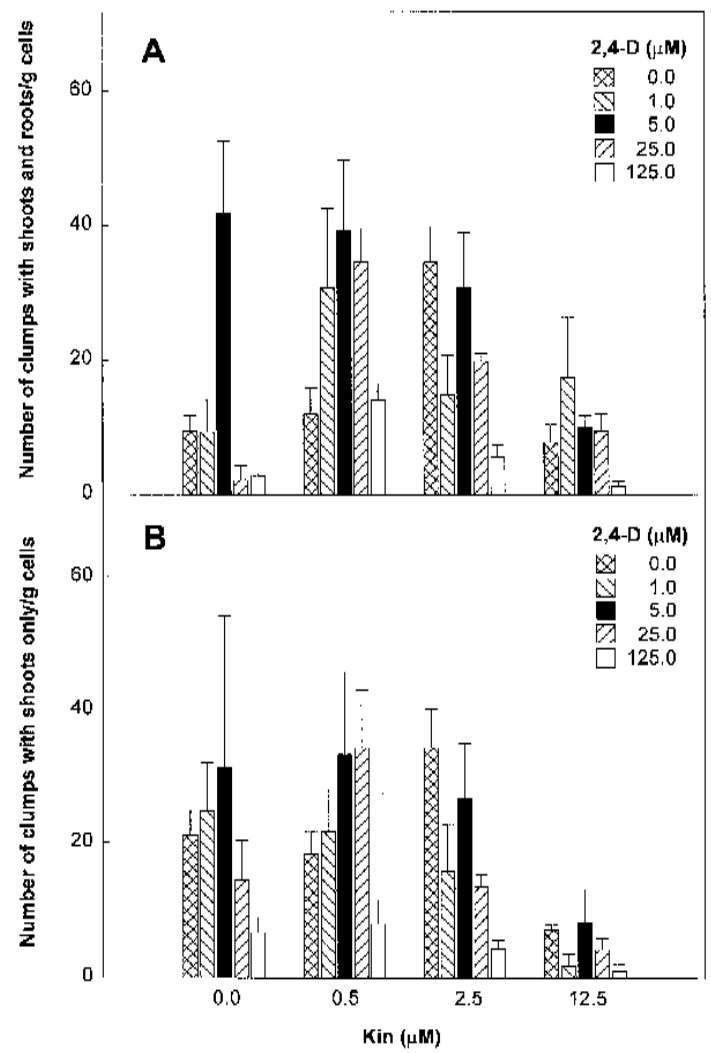

Fig. 4. Effects of 2,4-D and Kin combinations in MS-L medium on differentiation of shoots and roots from iris cell suspension culture. Number of regenerating clumps/gram cells that developed both shoots and roots (A), and number of regenerating clumps/gram cells that developed shoots only (B) 5 weeks after differentiated clumps were transferred to MS-D medium. Bars represent standard errors of the means, $\mathrm{n}=15$. curred only when 2,4-D was removed from the medium (Fujimura and Komamine, 1980; Kamo et al., 1990).

We found that plant growth regulators in the MS-L medium affected subsequent regeneration. Cells from the MS-L medium containing $5.0 \mu \mathrm{M} 2,4-\mathrm{D}$ and $0.5 \mu \mathrm{M}$ Kin produced the most differentiated clumps (Fig. 3A). Differentiated clumps from suspension-cultured cells grown in MS-L medium with $5.0 \mu \mathrm{M}$ 2,4-D and either $2.5 \mu \mathrm{M}$ Kin or without Kin had the best survival rates. Differentiated clumps from MS-L medium with 5.0 $\mu \mathrm{M}$ 2,4-D and either 0 or $2.5 \mu \mathrm{M}$ Kin were most likely to develop plantlets after transfer from MS-I to MS-D medium (Fig. 3B). A ratio of about 10:1 (2,4$\mathrm{D}:$ Kin) in the culture medium considerably enhanced regenerating callus formation of iris on agar medium (Gozu et al., 1993; Jéhan et al., 1994; Laublin et al., 1991). In the current study the best combination was $5.0 \mu \mathrm{M}$ 2,4-D and $0.5 \mu \mathrm{M}$ Kin (10:1). The major influence of $5 \mu \mathrm{M}$ 2,4-D in MS-L medium (Fig. 3) was consistent with that for cereal cultures (Vasil, 1988).

Halperin (1966) examined the regeneration capability of different-sized fractions in carrot suspension cultures. The $45-$ to $75-\mu \mathrm{m}$ fraction consisted of free cells and proembryogenic masses of various size and shape. These yielded a high percentage of embryos, which were joined in groups. The $<45-\mu \mathrm{m}$ fraction, containing mostly single cells and a small percentage of aggregate units of about two to five cells, produced a much lower percentage of embryos.

In the current study, cell clumps showed progressively higher regeneration potentials as sieve size decreased (Fig. 6). The highest regeneration rate was obtained from the fraction comprised of small cell aggregates $\leq 280$ $\mu \mathrm{m}$ (passing through a 50-mesh sieve). In other species, cells in smaller-sized clumps generally had very dense cytoplasm resembling embryogenic cell lines (Halperin, 1966). The larger the clumps, the more difficult it may be for the majority of the cells to respond to the inductive stimuli for morphogenesis. The physiological state of the larger clumps might not be suitable for regeneration. In contrast, clumps $\leq 190 \mu \mathrm{m}$ also demonstrated low regeneration. In carrot, the formation of primary differentiating states of the proembryogenic mass in the suspension culture was essential for further differentiation on an induction medium (Halperin, 1966). If the cell aggregates were too small, they could not reach the required size and regeneration could not proceed. Even in the appropriate physiological (regeneration-competent) state, only limited numbers of single cells can accommodate the changes if dissociated from the cell mass. Though the exact mechanism is unknown, the size of multicellular aggregates in suspension culture seems to be an important factor affecting regeneration efficiency.

The interval for subculturing of suspension cultures depends on the plant genotype, and usually ranges from 1-4 weeks (Kamo et al., 1990; Shimizu et al., 1996; Wang and Nguyen, 1990). Almost all research on regeneration 
Table 2. Mean squares from the analysis of variance for four parameters associated with plant regeneration from suspension cultured cells of Iris as a result of growth on media supplemented with Kin and 2,4-D in a $4 \times 5$ factorial experiment.

\begin{tabular}{lrcccc}
\hline $\begin{array}{l}\text { Source } \\
\text { of variation }\end{array}$ & df & $\begin{array}{c}\text { No. differentiated } \\
\text { clumps }\end{array}$ & $\begin{array}{c}\text { No. regenerating } \\
\text { clumps }\end{array}$ & $\begin{array}{c}\text { No. clumps with } \\
\text { shoots and roots }\end{array}$ & $\begin{array}{c}\text { No. clumps with } \\
\text { shoots only }\end{array}$ \\
\hline Kin & 3 & $8574^{* *}$ & $2534^{* *}$ & $732^{* *}$ & $1052^{* * *}$ \\
$2,4-D$ & 4 & $2193^{* *}$ & $3210^{* *}$ & $1057^{* *}$ & $605^{* *}$ \\
Kin $\times 2,4-D$ & 12 & $502^{*}$ & $506^{* *}$ & $206^{*}$ & $78^{\text {ss }}$ \\
Error & 40 & 249 & 105 & 101 & 167 \\
\hline
\end{tabular}

Ns,*,***Nonsignificant or significant at $P \leq 0.05$ or 0.01 , respectively.

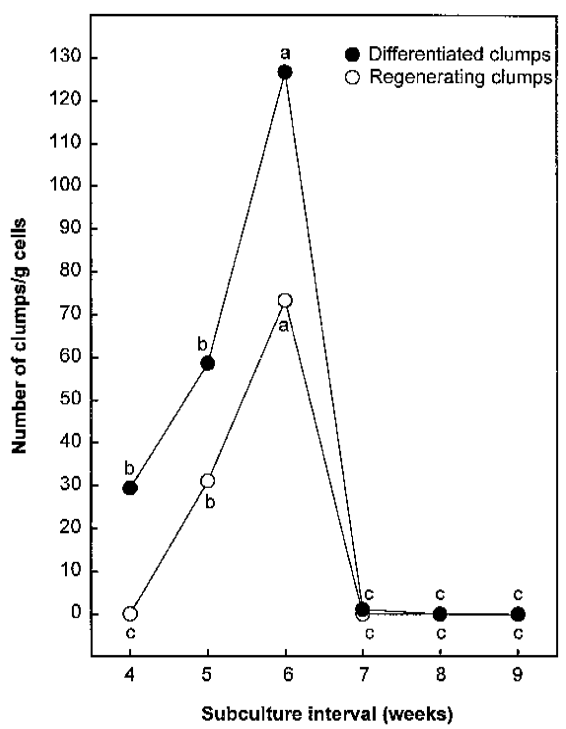

Fig. 5. Effect of subculture interval on number of differentiated clumps/gram cells 5 weeks after suspension-cultured cells of iris were transferred to MS-I medium ( ), and number of regenerating clumps/gram cells 5 weeks after the differentiated clumps were transferred to MS-D medium (O). Data points within the same clump type followed by different letters are significantly different $(P \leq 0.05)$ according to Duncan's multiple range test $(\mathrm{n}=15)$.

from suspension-cultured cells has focused on the type and concentration of growth regulators, medium composition, and culture conditions; there are no reports on the influence of the length of the subculture interval on regeneration efficiency from iris suspension culture. The most important finding in the present study may be that the length of the subculture interval had a remarkable effect on plant regeneration in Iris germanica 'Skating Party.' The subculture interval for regular maintenance of suspension-cultured cells was 3-4 weeks. If extended to 5 weeks, most cells or cell aggregates became necrotic soon after transfer to fresh MS-L medium. If, however, the cultures were kept intact in the same vessel for 6-7 weeks without subculturing, they were still recoverable and gave rise to the highest regeneration after transfer to MS-I medium. Beyond this period, both recovery and regeneration rates were sharply reduced. Cells in suspension cultures vary in physiological status over time and this is closely associated with regeneration competency.

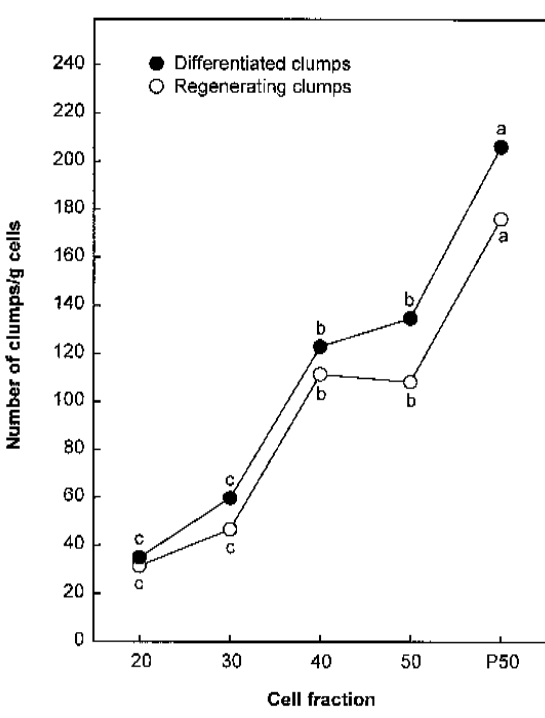

Fig. 6. Effect of the size of multicellular aggregates in suspension cultures on plant regeneration. Number of differentiated clumps/gram cells 5 weeks after suspension-cultured cells were transferred to MS-I medium ( $(\bullet)$, and number of regenerating clumps/gram cells 5 weeks after the differentiated clumps were transferred to MS-D medium (O). Each cell fraction retained on a particular sieve was assigned the number of the corresponding mesh size [20 $(860 \mu \mathrm{m}), 30$ $(520 \mu \mathrm{m}), 40(380 \mu \mathrm{m})$, and $50(280 \mu \mathrm{m})]$. The cell fraction passing through the 50-mesh sieve $(\leq 280 \mu \mathrm{m})$ was designated as P50. Within clump type, data points followed by different letters are significantly different $(P \leq 0.05)$ according to Duncan's multiple range test $(\mathrm{n}=15)$.

\section{Literature Cited}

Ammirato, P.V. 1978. Somatic embryogenesis and plant development in suspension cultures of the medicinal yam, Dioscorea floribunda. Amer. J. Bot. 65(suppl.):89.

Fujimura, T. and A. Komamine. 1980. The serial observation of embryogenesis in a carrot cell suspension culture. New Phytol. 86:213-218.

Fujino M., T. Fujimura, and K. Hamada. 1972. Multiplication of Dutch iris (Iris hollandica) by organ culture. J. Jpn. Soc. Hort. Sci. 41:66-71.

Gozu, Y., M. Yokoyama, M. Nakamura, R. Namba, K. Yomogida, M. Yanagi, and S. Nakamura. 1993. In vitro propagation of Iris pallida. Plant Cell Rpt. 13:12-16.

Halperin, W. 1966. Alternative morphogenetic events in

Hussey, G. 1976. Propagation of Dutch iris by tissue culture. Scientia Hort. 4:163-165.

Jéhan, H., D. Courtois, C. Ehret, K. Lerch, and V. Petiard. 1994. Plant regeneration of Iris pallida Lam. and Iris germanica via somatic embryogenesis from leaves, apices and young flowers. Plant Cell Rpt. 13:671-675.

Kamo, K., J. Chen, and R. Lawson. 1990. The establishment of cell suspension cultures of Gladiolus that cell suspensions. Amer. J. Bot. 53:443-453. regenerate plants. In Vitro Cell Dev. Biol. 26:425-430. Laublin, G., H.S. Saini, and M. Cappadocia. 1991. In vitro plant regeneration via somatic embryogenesis from root culture of some rhizomatous irises. Plant Cell Tiss. Org. Cult. 27:15-21.

Lu, C. and I.K. Vasil. 1981. Somatic embryogenesis and plant regeneration from freely-suspended cells and cell groups of Panicum maximum. Ann. Bot. 48:543-548.

Meyer, M.M., Jr., L.H. Fuchigami, and A.N. Roberts. 1975

Propagation of tall bearded irises by tissue culture. HortScience 10:479-480.

Mitra, J., M.O. Mapes, and F.C. Steward. 1960. Growth and organized development of cultured cells. IV. The behavior of the nucleus. Amer. J. Bot. 47:357-368.

Murashige, T. and F. Skoog. 1962. A revised medium for rapid growth and bioassays with tobacco tissue cultures. Physiol. Plant. 15:473-497.

Novak, F.J., R. Afza, and M. VanDuren. 1989. Somatic embryogenesis and plant regeneration in suspension cultures of dessert (AA and AAA) and cooking (ABB) bananas (Musa spp.). Bio/Technology 7:154-159.

Radojević, L.J. and P. Landré. 1990. Ultrastructure studies of the somatic embryogenesis in Iris spp. cultures. Proc. 7th Intl. Congr. Plant Tissue and Cell Culture, Amsterdam, The Netherlands (Abstr.) B4-100.

Radojević, L.J., O. Sokic', and B. Tucić. 1987. Somatic embryogenesis in tissue culture of iris (Iris pumila L.). Acta Hort. 212:719-723.

Radojević, L.J. and A. Subotić. 1992. Plant regeneration of Iris setosa Pall. through somatic embryogenesis and organogenesis. J. Plant Physiol. 139:690-696.

Reinert, J. and D. Backs. 1968. Control of totipotency in plant cells growing in vitro. Nature 220:1340-1341.

Reinert, J., D. Backs-Huseman, and H. Zerban. 1970. Determination of embryo and root formation in tissue cultures from Daucus carota. Les Culture de Tissus de Plantes. Colloq. Intl. No. 193:261-268, Centre Natl. Res. Sci., Strasbourg, France.

Reuther, G. 1977. Embryoide Differenzierungsmuster im Kallus der Gattungen Iris und Asparagus. Ber. Deutsch. Bot. Ges. 90: 417-437.

Shimizu, K., H. Nagaike, T. Yabuya, and T. Adachi. 1997. Plant regeneration from suspension culture of Iris germanica L. Plant Cell Tiss. Org. Cult. 50:27-31.

Shimizu, K., T. Yabuya, and T. Adachi. 1996. Plant regeneration from protoplasts of Iris germanica L. Euphytica 89:223-227.

Smith, S.M. and H.E. Street. 1974. The decline of embryogenetic potential as callus and suspension cultures of carrot (Daucus carota L.) are serially subcultured. Ann. Bot. 38:223-241.

Steward, F.C. 1967. Totipotency of angiosperm cells. Its significance for morphology and embryology. Phytomorphology 17:469-507.

Sussex, I.M. and K.A. Frei. 1968. Embryoid development in long-term tissue cultures of carrot. Phytomorphology 18:339-349.

Syono, K. 1965. Changes in organ forming capacity of carrot root calluses during subcultures. Plant Cell Physiol. 6:403-419.

Torrey, J.G. 1958. Differential mitotic response of diploid and polyploid nuclei to auxin and kinetin treatment. Science 128:1148.

Torrey, J.G. 1967. Morphogenesis in relation to chromosomal constitution in long-term plant tissue cultures. Physiol. Plant. 20:265-275.

Tsukahara, M., T. Hirosawa, and S. Kishine. 1996. Efficient plant regeneration from cell suspension cultures of rice (Oryza sativa L.). J. Plant Physiol. 149:157-162.

van der Linde, P.C.G., G.M.G.M.Hol, G.J.Blombarnboorn, J. van Aartrijk, and G.J. de Klerk. 1988. In vitro propagation of Iris hollandica Tub. cv. Prof. Blaauw. Regeneration on bulb scale explants. Acta Hort. 226:121-128.

Vasil, I.K. 1988. Progress in the regeneration and genetic manipulation of cereal crops. Bio/Technology 6:397402

Vasil, V. and I.K Vasil 1982. Characterization of an embryogenic cell suspension culture derived from cultured inflorescence of Pennisetum americanum. Amer. J. Bot. 69:1441-1450.

Wang W.C. and H.T. Nguyen. 1990. A novel approach for efficient plant regeneration from long-term suspension culture of wheat. Plant Cell Rpt. 8:639-642.

Yabuya, T., Y. Ikeda, and T. Adachi 1991. In vitro propagation of Japanese garden iris, Iris ensata Thunb. Euphytica 57:77-81. 